\title{
What Germany's University Beginners Think about Water Reuse
}

\author{
Sarah Schmid * (iD and Franz X. Bogner
}

ZMNU (Centre of Math \& Science Education), Department of Biology Education, University of Bayreuth, NW-1, D-95447 Bavaria, Germany; franz.bogner@uni-bayreuth.de

* Correspondence: sarah.schmid@uni-bayreuth.de; Tel.: +49-921-2598

Received: 23 April 2018; Accepted: 30 May 2018; Published: 4 June 2018

\begin{abstract}
Water reuse is a new technology, not yet implemented, but discussed for use in Germany. Public opinion plays a major role in the success of the introduction of this new technology and was not yet analyzed for Germany. When monitoring 340 university beginners' conceptions regarding water reuse, a variety of conceptions appeared. While usage of tap water is accepted for drinking purposes, acceptance of recycled water for oral consumption was low. When asked for reasons for (not) using recycled water, three groups of respondents were extracted: (a) The acceptors (convinced of quality, or naming sustainability as a reason); (b) the undecided (doubts about quality, rejection of its use for consumption, and psychological conflicts of logic and disgust); (c) the non-acceptors (unconvinced of quality and preference for bottled water). When asked about factors that would lead to accepting the use of recycled water, insights into treatment processes were identified as the most convincing, followed by educational films and guided tours. Participants showed high conviction about currently existing tap-water qualities. Having water that is cleaned before it reaches the consumer was reported to have high priority. To increase acceptance of water reuse, recommendations for appropriate outreach programs are discussed.
\end{abstract}

Keywords: water reuse; recycled water; attitudes; adolescents

\section{Introduction}

Germany is a densely inhabited country in the center of Europe, with an area of $357,138 \mathrm{~km}^{2}$ and about 82 million inhabitants. It largely exceeds the European population density mean of $116 \mathrm{p} / \mathrm{km}^{2}$ with its $229 \mathrm{p} / \mathrm{km}^{2}$. Berlin has the highest population density in Germany with $3945 \mathrm{p} / \mathrm{km}^{2}$. Although the overall water supply volume is sufficient, there are already regional and seasonal water shortages. However, extremely high population densities, intensified agriculture, and industrial impacts affect water quality. A total of $99 \%$ of inhabitants are connected to the public drinking water supply and public sewage systems. About 5 billion $\mathrm{m}^{3}$ per year are used for supplying households and small businesses with drinking water. The minimum requirements of a good water supply in Agenda 21, Chapter 18 are met. A main concern is the renewal and adaption of existing systems to meet changed population densities and climatic changes. Expected effects of climate change are reduced amounts of rainfall, and subsequently less raw water availability in summer time. Together, with expected further increase of population densities aligned with increased demand for drinking water, current wastewater treatment and drinking water supply may reach their limits in Germany [1].

Drinking water is the best-controlled food in Germany. Water supply in Germany is coordinated locally but underlies national and international regulations, like the European Union (EU) Water Framework Directive 2000/60/EC (WRRL) [2], the Agenda 21 of the United Nations (Chapter 18) [3], the Federal Water Act [4], the drinking water ordinance [5], or the wastewater ordinance [6]. Within the last 40 years, the reduction of pollution of water bodies has yielded large effects. 
The quality of surface waters rose a lot. Nevertheless, many water bodies are unhygienic and in bad chemical condition, which does not allow for bathing, fishing, or use for drinking water production. More effective cleaning of sewage plant output should be considered as one possibility for further reduction of water body pollution [1].

Unplanned (de facto) potable reuse already occurs in many major European cities [7]. This means that sewage plant output in rivers is still measurable where water works take up their raw water, leading to poorer quality raw water [8]. New technologies may help to provide drinking water without needing to permanently take raw water from natural resources, and may also help increase raw water availability and quality of raw water resources. The further treatment of wastewater after its treatment in a sewage plant is already an important issue in several EU and non-EU countries, where water shortages are common $[1,9,10]$. Sewage plant outputs are then cleaned further for fit-for-purpose requirements, like agricultural applications, industrial needs, or even drinking purposes. This can either be planned indirect uses, i.e., sewage output cleaned to drinking water quality that is given back to nature to increase quality of raw water and then further processed by water works, or planned direct potable reuse, i.e., the direct use of cleaned sewage plant output for drinking purposes. Nowadays, supplying drinking water to households directly from wastewater treatment supplies is technologically possible; examples exist in Kuwait [9], the USA [11], Australia [12], and Singapore [8,13]. However, public acceptance of such procedures remains limited $[9,14]$. Although modern wastewater treatment technologies can turn wastewater into recycled water of a better quality than existing potable water standards [15,16], without public acceptance, an introduction of recycled water may fail [17-19]. Binz and colleagues state that introducing a new technology depends on how much it contradicts established worldviews [17]. For public acceptance, the technology and the way it is viewed must be changed simultaneously over time. Examples from the past are the introduction of electric light or automobiles. Potable water reuse should be considered an innovation that strongly contradicts social beliefs and norms, and it needs careful introduction.

The socio-economic variable that most affects the acceptance of recycled water has repeatedly been education [19]. Educating the public to understand the processes of converting wastewater to drinking water may be a major precondition to reaching acceptance-a difficult task, as even university beginners lack the most basic knowledge of the current urban water cycle despite having learnt about it in school [20]. This study described misconceptions about the urban water cycle. Students imagined closed pipe-to-pipe-like systems, where sewage plants clean sewage to drinking water quality, waterworks distribute the cleaned water to consumers, and nature played no role in the cleaning process. Likewise, Alhumound and Madzikanda described a lack of basic understanding about wastewater treatment by adult residents of Kuwait [9]. To make it clear, the global natural water cycle is a closed system, with the same water being recycled and used over and over again [21]. In human-made urban water cycles, nature still plays a major role in the cleaning and recycling process as sewage plant output is not of drinking water quality in general. Water reuse projects clean sewage plant output further by, for example, replenishing available freshwater resources with water of drinking water quality, or directly providing drinking water [12]. A current national project (abbreviated "TrinkWave") is constructing a prototype of a water-recycling unit with output of drinking water quality for use in Germany. It was of interest to understand how German university beginners rate the hypothetical use of technologically recycled water. The study represents the first survey of its kind with a German sample. In the following, when we speak of "recycled water", we mean water cleaned through technological processes from sewage plant output to drinking water quality.

Monitoring student conceptions with qualitative content analysis is an established way to analyze what is known or believed by students [22]. In addition to studying students' conceptions, the analysis of their current and planned behavior can identify perceived obstacles and motivators, such as the introduction of recycled water. This can result in implementations for out-of-school education. Educational offers that consider the beliefs, fears, and open questions of adolescents have the potential 
to reduce rejection through elucidation. We believe that informed citizens should be able to participate in political discussions concerning changes in water supply.

The objectives of our study were twofold: (1) Which attitudes and potential fears exist among high achievers regarding the hypothetical usage of drinking water directly recycled from wastewater? (2) Are these attitudes and fears based on, or linked to, misconceptions concerning the human-controlled water cycle?

\section{Materials and Methods}

This study asked 340 university beginners to fill in a 10-15 min paper-and-pencil questionnaire in their first week of their first semester (Table 1$)$. The average age was 19.5 years $( \pm 1.88 \mathrm{SD}), 53.3$ percent were female. All were on-campus students. Students ready to begin their studies in Biology, Chemistry, Biochemistry, Teaching, Geography, Economics, and Law participated. Participation was voluntary. All participants gave their oral consent before participating. The study was conducted in accordance with the Declaration of Helsinki [23]. The questionnaire was approved by the ethics committee of the University of Bayreuth. Data was collected pseudo-anonymously. Students cannot be identified by represented data in this study. Answers to open questions were analyzed using qualitative content analysis [24]. They were categorized by a single decider, and a $20 \%$ subsample of the data was independently reanalyzed to obtain independent interrater reliability estimates. Additionally, the first author rated all data again seven months later to estimate intra-rater statistics. Intra- and interrater Cohen's kappa coefficients were calculated for all open questions (Q3j: Intra-rater value: 0.86, interrater value: 0.87; Q4: Intra-rater value: 1, interrater value: 1. (High values of Q4 occurred because only a few people used the option to add another reason and the named reasons were simple to differentiate). Cohen's kappa coefficients above 0.75 indicate a very good overlap between the raters. Statistical analyses were calculated using SPSS.

We believe that most students had not heard about recycled water before, as this topic is not an issue of public discussion in Germany. Responses are therefore considered to be first thoughts about this issue. Any experience with recycled water was regarded as non-existent and thus not influenced by interest groups. To our knowledge, this is the first study regarding students' thoughts on recycled water.

Table 1. Questionnaire questions. Except for Q3j and Q4, all questions were closed questions with a Likert scale of 1 (refusal/never) to 4 (agreement/always).

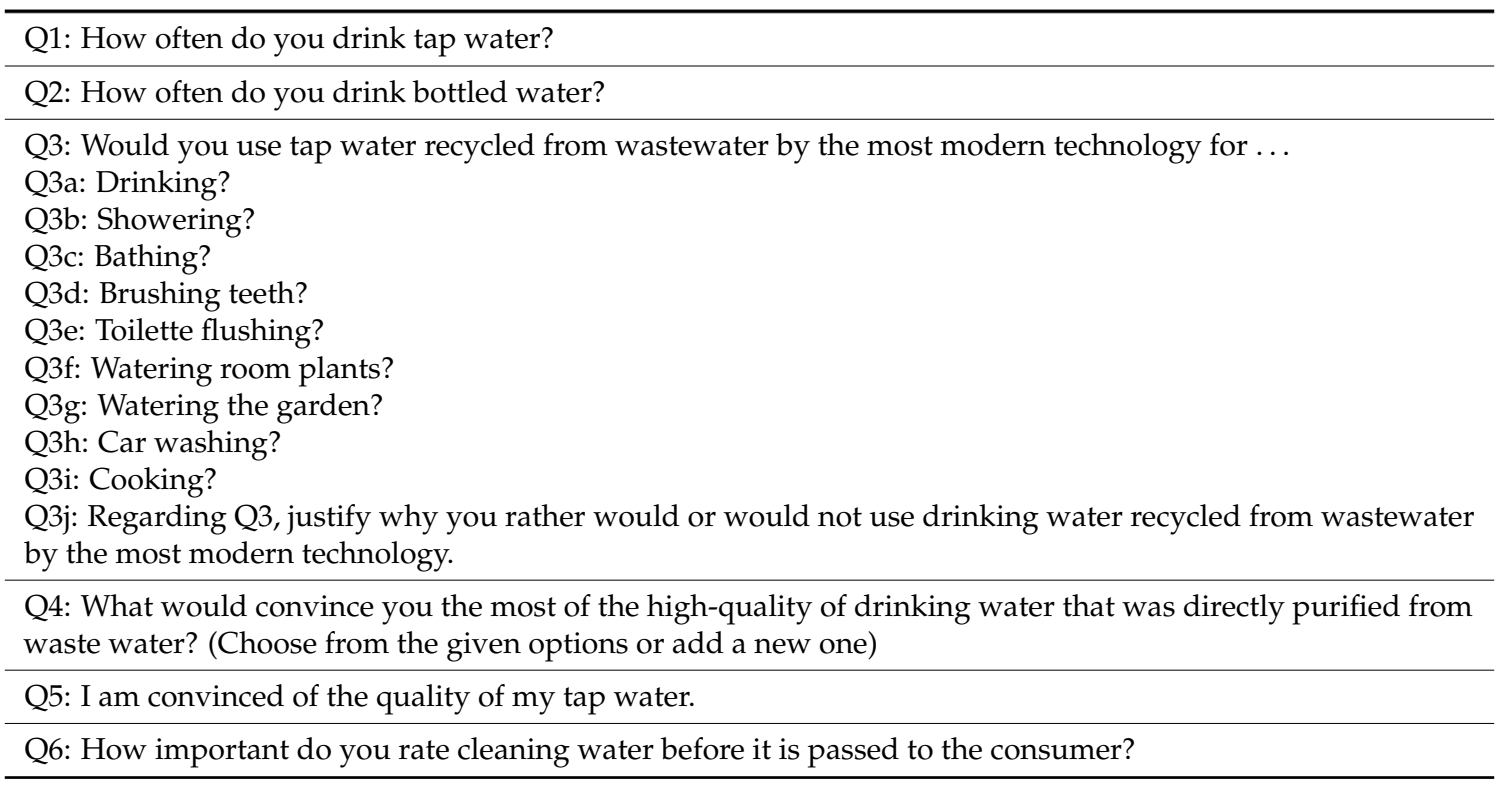




\section{Results}

University beginners have no preference for tap water $(\mathrm{M}=2.71$; $\mathrm{SE}=0.055)$ or bottled water $(\mathrm{M}=2.67 ; \mathrm{SE}=0.005 ; \mathrm{t}(341)=0.346 ; p=$ n.s.; $t$-test; Figure 1A). Both questions score about average. Students in general are convinced of the quality of their tap water $(\mathrm{M}=3.19)$. They consider the cleaning of water before it is passed on to the consumer to be very important ( $\mathrm{M}=3.88$; Figure 1B).

Ratings of different kinds of usage for recycled water are presented in Figure 2. Our sample tended to accept its use, as only one category fell below the average scale mean of 2.5 . They preferred recycled water for non-consumption categories like toilet flushing, car washing, and for watering plants inside or outside the house, while brushing teeth with, and bathing in, recycled water as options were less accepted. Least accepted were the cooking, drinking, and showering categories—options that happen daily and involve a high amount of water and consumption.
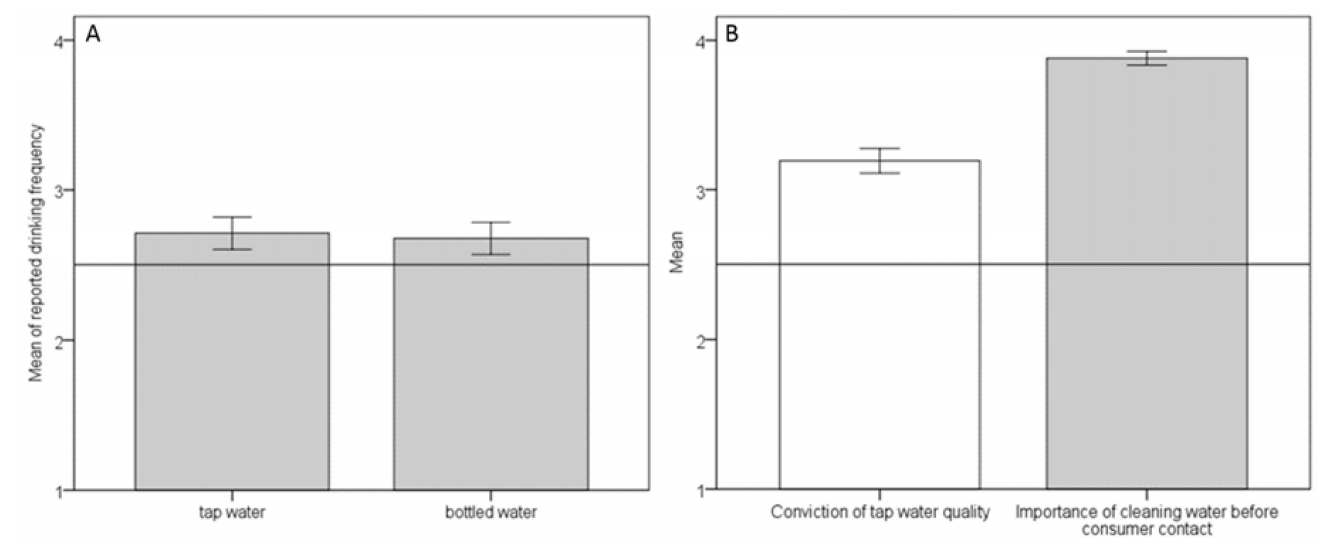

Figure 1. (A) Q1 and Q2: “How often do you drink" Q1) “. . tap water?" Q2) “ . . bottled water?" (B) Q5: "I am convinced of the quality of my tap-water" and Q6: "How important do you rate the cleaning of water before it is passed to the consumer?" Line represents the mean of rating options (2.5). Error bars (95\% CI).

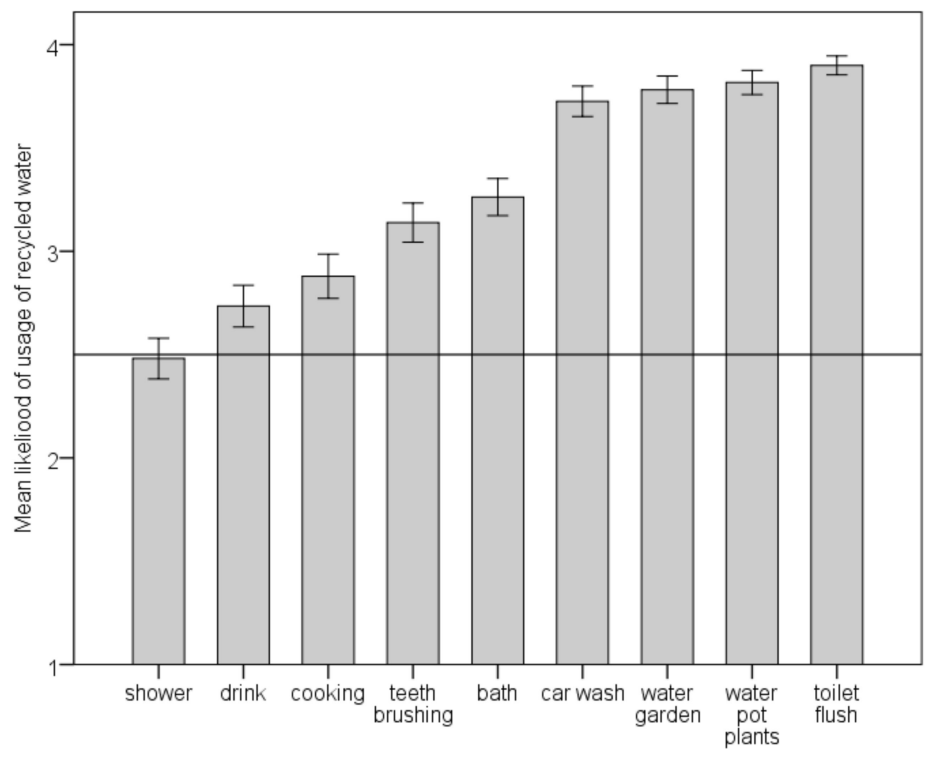

Figure 2. Q3: "Would you use tap water recycled from wastewater by the most modern technology for ... ". Line represents the mean of rating options (2.5). Error bars (95\% CI). 
Based on the answers to the question why technologically recycled water should (not) be used, several categories were extracted: Obvious reasons were "being convinced of the water quality" ( $26 \%$ of statements) and "sustainability" (9\%). Reasons to use it with restrictions were "if it really is clean" $(10 \%)$ and "using it, but not for drinking" (10\%). Others were categorized into a "psychological conflict" $(14 \%)$; they know logically that it would be clean, but the knowledge that it had been wastewater would leave them undecided because of disgust. Students that stated they would definitively not use it justified their decision with "not being convinced of the water quality" (13\%) or with "preferring bottled water" (2\%); see Figure 3.

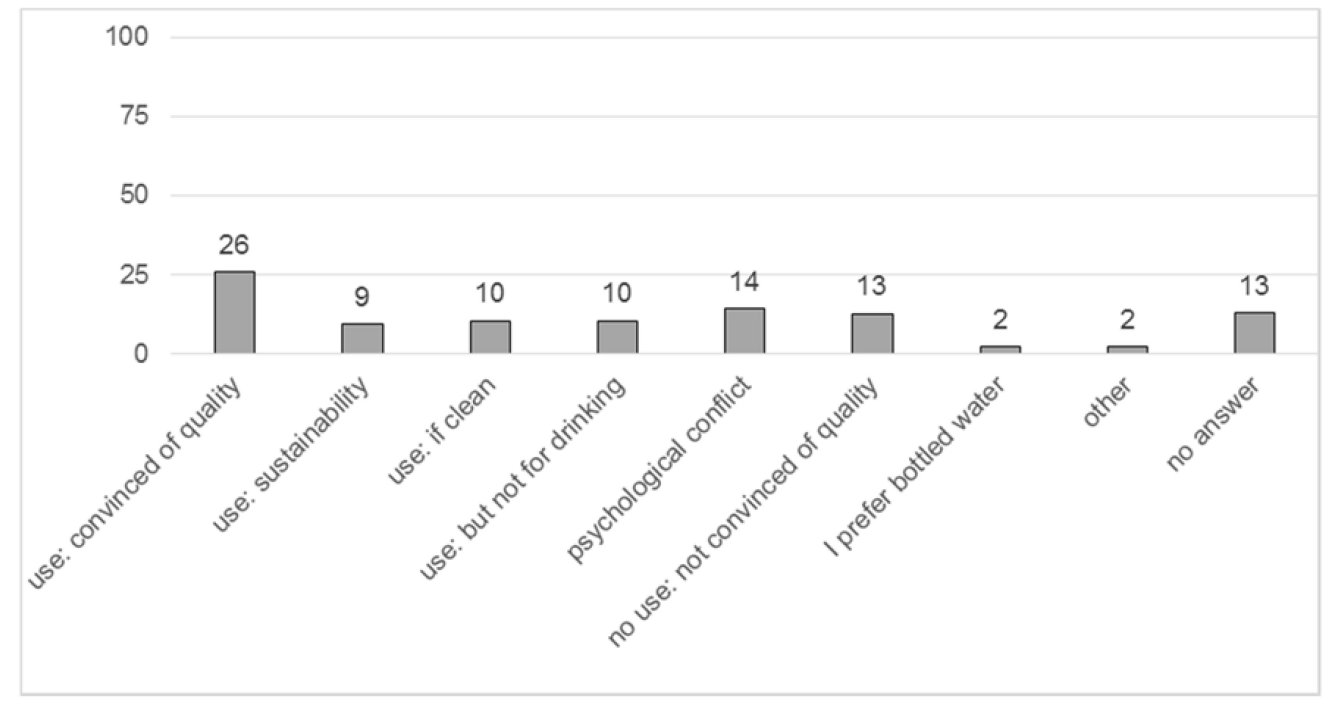

Figure 3. Q3j: "Regarding Q3, justify why you rather would or would not use drinking water recycled from wastewater by the most modern technology." $\mathrm{N}_{\text {Students }}=340, \mathrm{~N}_{\text {Statements }}=425$. All statements add up to $100 \%$. Open question with categories formed from answers given.

The majority would be convinced of the quality of recycled drinking water if 'insight into the treatment processes' of wastewater to clean tap water were available (35\% of statements; Figure 4$)$. As examples of this, 'educational films' were chosen $19 \%$ of the time and 'guided tours' $17 \%$. The category 'test results', together with the categories 'seeing a person convinced of the quality', 'seeing a person that uses the recycled water', or 'taking part in a guided tour in a household already using it' would only convince a few students $(<10 \%)$. Only a few students stated that nothing would convince them $(2 \%)$.

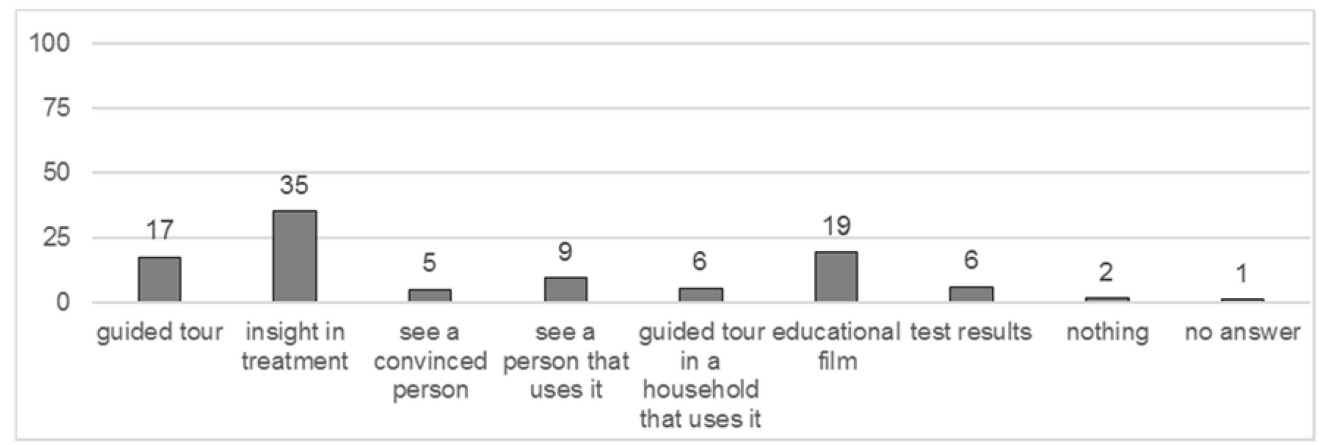

Figure 4. Q4 "What would convince you the most of the high-quality of drinking water that was directly purified from waste water? Choose from the given options or add a new one." $\mathrm{N}_{\text {Students }}=340$, $\mathrm{N}_{\text {Statements }}=706$. All statements add up to $100 \%$. "Test results" was the only relevant answer added by participants. All other listed options were already provided. 


\section{Discussion}

\subsection{Relevance of Reuse and Estimation of Acceptable Usage}

University beginners in Germany report that they consume tap water on a regular basis and have no preference for bottled water over tap water, which is in line with Fremerey and colleagues [25]. A change from current sewage plants to water-reuse systems can be seen as relevant, affecting students' daily lives. In Kuwait, where recycled water availability is already common, the majority of inhabitants do drink both tap and bottled water. However, the majority would not want to use recycled water for drinking when explicitly asked [9]. In our study, hypothetical technologically recycled drinking water made from wastewater found its highest acceptance in activities not involving oral consumption of water, such as watering the garden or pot plants, toilet flushing, or car washing; other non-consumption activities would probably be rated likewise. Therefore, this would be a field where the water industry could expect high acceptance of usage of recycled water. However, activities with oral water consumption or close body contact were less well accepted. Interestingly, showering was the least accepted category. We assume people may have thought of not feeling clean after using technologically recycled water. These results are in line with earlier studies regarding public acceptance preferences of recycled water [26,27]. It has repeatedly been found that the public is rather open to using recycled water for activities involving low personal contact and rather less open to usage in those with high personal contact [18,19]. As drinking water operators cannot offer different pipes for each household, a separation of this kind is unlikely for the consumer. In outreach activities, it would be of interest to start with the stated likely accepted usages to visualize a first consensus for safe usage. For discussing rejected usages, analyzing the underlying reasons is needed first.

\subsection{Reasons For and Against Usage}

When asked for reasons why students would rather (not) use technologically recycled water, three distinct participant groups could be identified. The majority belongs to the acceptors, who name two reasons: (1) They are convinced of the quality of recycled water, e.g., DET-008 wrote: "There is nearly no doubt about the purity"; (2) They find it a necessary and wise thing to do regarding sustainable future resource management, e.g., DET-006 wrote: "Due to water shortages in many countries, it will be necessary to use water consistently in the future". For implementation plans, this group would need no severe educational activities in the first place. They can be regarded as being already convinced of the project idea and can act as multipliers for distributing positive information and positive feelings in their social environment. As this group has positive attitudes towards the project idea, this group can also be regarded as having certain expectations that should be queried to analyze if the expected positive outcomes can be realized or if the expectations would be unrealistic or too high. Questionnaires used for gaining a representative sample of the inhabitants of the city where the project would be implemented should include an option to voluntarily ask for contact information of the participant. With this, a sub-sample of the acceptor group could be addressed specifically to obtain detailed data on expectations.

The second largest group of our sample are the undecided. The group names three reasons: (1) They would use it, if it would be really clean and safe, e.g., DET-007 wrote: "I would rather use it, if it is made sure that the water is really clean and of high quality"; (2) They would use it, but not for drinking because of remaining doubt about the quality, e.g., DET-029 wrote: "I do not trust the cleaning processes $100 \%$. For example, in respect to the cleaning of medical substance. Therefore, I do not have absolute trust in respect to consumption. Concerning showering or other usages, I don't care so much about it"; (3) They know it would be clean, but the knowledge that it had once been wastewater creates a psychological conflict between logic and disgust, e.g., DET-028 wrote: "In general, I would not be averse to the usage of recycled water in all life-areas. However, the thought of using used-to-be-wastewater for e.g., cooking or tooth brushing seems worrying". This group is the most valuable for educational outreach. In the process of public discussion, they probably will decide on 
their preferences for or against the project. Right now, they are undecided, but at the same time have not yet had informational material for or against the project. For the project, it would be beneficial if they would turn into acceptors. The first named uncertainty is a question regarding the quality the recycled water would have. This group should be provided with information about current and planned risks of their drinking water. This can be existent and planned thresholds for chemicals, bacteria, viruses, medical substances, and so on. Information about how thresholds are set, who decides them, and who controls them can be regarded of interest to the critical citizen. The second uncertainty addresses water quality, especially for oral consumption. Here information on the long-term effects of drinking water that applies to the set thresholds would be needed. Additionally, the actual cleaning processes of the technical plant should be explained to show how the thresholds are reached. Another important point should be the discussion of emergency plans to answer the question of what would happen if some part of the technical plant fails to work as it should. The third uncertainty is of a psychological kind. Additional to the rational facts for quality safety, a positive image should be created for recycled water.

The last and smallest group are the non-acceptors, raising mainly two reasons: (1) They are not convinced that the water would be of good quality, e.g., DET-046 wrote: "Because I cannot believe that, in spite of the most modern techniques, all microscopic small and threatening germs and certain chemicals can be retrieved from the water, I would not use it"; (2) They prefer bottled water (for consumption), e.g., DET-017 wrote: "It would not bother me in other areas of the house, but for drinking I prefer bottled water, due to its taste". Addressing the non-acceptors in educational outreach is more difficult, as they have a rather negative attitude towards the project before receiving positive or negative information. It is possible that they would not want to participate in outreach education or information events. However, if they participate, most concrete and detailed information needs to be at hand to answer concerns in a satisfactory way. The information needs to be prepared using understandable terminology, but provide detailed information. In our sample, the non-acceptors again hold health concerns and the above-mentioned strategy can be applied. The second concern is a personal preference for bottled water for oral consumption. This group could probably be influenced through offering to test the taste of recycled water. However, this group can also be regarded as being indifferent to the subject of a change to their tap water, as they already prefer bottled water.

As the university beginners are considered high achievers (holding a university entrance diploma), it is in line with the literature, which states that the majority would accept recycled water. It has been repeatedly found that the higher the educational level, the higher the likelihood of acceptance (e.g., Reference [12]). In line with our results, Marks and colleagues [28] found perceived positive effects on the environment as a major reason for using recycled water. Similar to our results, Alhumound and Madzikanda [9] found health to be the number one reason not to use recycled water, closely followed by psychological conflicts.

\subsection{Options for Educational Outreach}

When asked what would convince our participants best of the good quality of recycled water, the majority voted for insights into treatment processes. Educational films and guided tours were the second most convincing options. Other options were less prominent. Therefore, water suppliers should provide information about how exactly they (plan to) process wastewater into drinking water. We suggest providing explanations at different pre-knowledge levels to address all consumers, from explanations without pre-knowledge requirement of chemistry, biology, and engineering, to information that provides deep details of involved processes. Dolnicar and colleagues [29] found that the stated likelihood of using recycled water indeed rose when information about the production process was provided.

\subsection{Necessity of Improvement for Wastewater Treatment Despite no Current Risks?}

Encouragingly, university beginners are on average quite convinced of the current quality of their classically cleaned drinking water. Furthermore, cleaning of water before it is passed on to 
consumers is already considered immensely important. It should be made especially clear that tap water quality would definitely not drop in quality with the new technology, but rather rise. It is important to note here that the reduction of threats, as compared with the classical sewage plant, should be highlighted. Interestingly, students stated that cleaning is most important to them, although they lack basic knowledge of the current cleaning processes [20]. This lack of basic knowledge can be assumed to be critical when it comes to the introduction of new technologies. The system as they know it apparently works, therefore the following question automatically arises: Why is a change of the water supply system necessary at all? The problem here is that the public is told that drinking water is the best controlled food in Germany, which is correct, but at the same time this fact may support the feeling that a change to using recycled water is unnecessary and that the unfamiliar system may have flaws. However, only a few people know that in many European urban areas, water cycles actually include the uncontrolled reuse of wastewater [15,30]. Information made available by waterworks and sewage plants to the public in Germany said that their tap water is perfectly clean of everything. This has changed in recent years, and the information has been adapted to meeting thresholds of bacteria and other potential threats listed in the drinking water ordinance [5]. However, this information itself unsettled the public, for example, bacteria were regarded as something bad in any concentration and without differentiation of species. Additionally, people wondered what had suddenly caused bacteria to appear in their drinking water, although nothing had happened to it, and only the information had been adapted (informal information from public outreach guide, BWB, Berlin). Bixio and colleagues $[7,15]$ also concluded that the provision of new information may lead to lower acceptance from the public due to the high emotive load of the topic.

Knowledge about the current urban water cycle seems to play only a secondary role; emotions seem to predominate in the introduction of the new technology [17]. Dolnicar and Schäfer [12], for example, reported that Australians were mainly concerned about health in connection with using recycled water, although they only had a low level of knowledge about its potential health risks. What and how the public is informed is immensely important to avoid misinterpretation. Provision of appropriate information, therefore, seems to be crucial to first resolve concerns and then implement change $[17,20]$. The public first needs to understand the current problems sewage plants face today. This includes known and unknown substances with potential health risks, or the occurrence of unplanned (de facto) wastewater reuse. Knowledge of unplanned reuse was found to contribute to a higher level of acceptance of planned reuse $[9,17,30]$. Misconceptions need to be carefully opposed. A positive vocabulary for the recycled water is expected to have a positive impact on its acceptance [17]. Even small changes, like more positive symbols used for recycled water, can make a difference in levels of acceptance [31]. Concerns about insufficient removal of microorganisms need to be taken seriously. Concerns about certain chemical substances, like pharmaceuticals, need to be discussed, as research is missing on long-term effects of exposure to, or accumulation of, these per se rather low-risk substances [32]. Risk assessment of these substances is needed; these unresolved questions regarding health risks are of great importance [12,33]. Although our sample mainly named health concerns, other factors are important for acceptance that are cited in literature are trust of water authorities and perception of fairness in terms of price [28,34]. Besides outreach educational campaigns for the public, critical points for success of implementation of water reuse plants are the involvement of various stakeholder groups (industry, health, academia, and community organizations), including trusted persons in public life (local politician, religious leaders). Just focusing on the technological safety and necessity of the introduction of the technology is insufficient to change the technology's reputation [17]. It is also of interest to oppose negative emotional news of scare campaigns with ones containing positive contents; presenting information for or against water reuse has an impact on the stated likelihood of acceptance of recycled water [35]. The introduction of water reuse to a new community could benefit from successful water reuse projects with positive outcome, like in Orange County (CA, USA), Windhoek (Namibia), Singapore, or even the International Space Station. 


\section{Conclusions}

Germany's university beginners in general have positive attitudes towards water reuse. However, many doubts about the true quality of the hypothetical reused water exist. It would be of interest to set new or use established quality standards for the reused water. Several persons from the acceptors stated that they would have no problem with usage, as the water would have drinking water quality-a well-known and accepted standard that guarantees lifelong risk-free consumption of drinking water. The application of similar quality standards for reused water and its educational preparation for outreach education in easily comprehensible words could lead the large group of the undecided to shift towards acceptance in terms of health and disgust.

Changing the social acceptability of a new technology takes years [12,17]. Should German water authorities consider introducing recycled water for households, they will need to consider starting public outreach activities and stakeholder networking before our current sewage plants exceed their limits so that the public can adapt to the notion that planned water reuse is something positive. Hurliman and Dolnicar found that a too rapid implementation of water reuse can lead to public rejection and abandonment of the planned project [35]. To sum up, results from international literature on public notions of planned water reuse also match the results for Germany's university beginners.

Author Contributions: S.S. designed and performed the experiments, analyzed the data, and wrote the paper. F.X.B. contributed in a close improvement editing process to write the paper.

Funding: The study was funded by TrinkWave (WAVE2015-820-3290-055-TrinkWave): BMBF (Federal Ministry of Education and Science); the German Research Foundation (DFG), and the University of Bayreuth in the funding program Open Access Publishing.

Conflicts of Interest: The founding sponsors had no role in the design of the study; in the collection, analyses, or interpretation of data; in the writing of the manuscript, or in the decision to publish the results

Limitations: The sample does not represent the overall German population, as it is restricted to university beginners at one university. Participants rated the hypothetical use of a product not yet available to them, which had little or no media presence so far.

\section{References}

1. Bartel, H. Wasserwirtschaft in Deutschland. Teil 1, Grundlagen; Umweltbundesamt (UBA): Dessau-Rosslau, Germany, 2014.

2. Völker, J.; Mohaupt, V. Die Wasserrahmenrichtlinie: Deutschlands Gewässer 2015; Umweltbundesamt (UBA): Dessau-Roßlau, Germany, 2016.

3. United Nations. Agenda 21: Konferenz der Vereinten Nationen für Umwelt und Entwicklung-Rio de Janeiro, Juni 1992; Bundesministerium für Umwelt, Naturschutz und Reaktorsicherheit (BMU): Berlin, Germany, 1997.

4. Bundesministeriums der Justiz und für Verbraucherschutz (BMJV). Gesetz zur Ordnung des Wasserhaushalts: Wasserhaushaltsgesetz-WHG; BMJV: Berlin, Germany, 2009.

5. BMJV. Verordnung über die Qualität von Wasser für den menschlichen Gebrauch: Trinkwasserverordnung-TrinkwV. BMJV: Berlin, Germany, 2001.

6. BMJV. Verordnung über Anforderungen an das Einleiten von Abwasser in Gewässer: Abwasserverordnung-AbwV in der Fassung der Bekanntmachung vom 17; BMJV: Berlin, Germany, 2017; Juni 2004 (BGBl. I S. 1108, 2625); die zuletzt durch Artikel 121 des Gesetzes vom 29. März 2017 (BGBl. I S. 626) geändert worden ist.

7. Bixio, D.; Thoeye, C.; De Koning, J.; Joksimovic, D.; Savic, D.; Wintgens, T.; Melin, T. Wastewater reuse in Europe. Desalination 2005, 187, 89-101. [CrossRef]

8. Rice, J.; Westerhoff, P. Spatial and temporal variation in de facto wastewater reuse in drinking water systems across the U.S.A. Environ. Sci. Technol. 2015, 49, 982-989. [CrossRef] [PubMed]

9. Alhumound, M.J.; Madzikanda, D. Public Perceptions on Water Reuse Options: The case of Sulaibiya wastewater treatment plant in Kuwait. Int. Bus. Econ. Res. J. 2010, 9, 141-158.

10. International Water Management Institute (IWMI). Insights from the Comprehensive Assessment of Water Management in Agiculture; Comprehensive Assessment Secretariat: Pelawatte, Sri Lanka, 2006; pp. 1-33.

11. Bruvold, W.H. Public opinion on water reuse options. J. Water Pollut. Control Fed. 1988, 20, 45-49. 
12. Dolnicar, S.; Schäfer, A.I. Desalinated versus recycled water: Public perceptions and profiles of the accepters. J. Environ. Manag. 2009, 90, 888-900. [CrossRef] [PubMed]

13. Jiménez, B.; Asano, T. Water Reuse: An International Survey of Current Practice, Issues and Needs; IWA Publishing: London, UK, 2008.

14. Hurlimann, A.; Dolnicar, S. Acceptance of water alternatives in Australia-2009. Water Sci. Technol. 2010, 61, 2137-2142. [CrossRef] [PubMed]

15. Bixio, D.; Cikurel, H.; Muston, M.; Miska, V.; Joksimovic, D.; Schäfer, A.I.; Ravazzini, A.; Aharoni, A.; Savic, D.; Thoeye, C.; et al. Municipal wastewater reclamation: Where do we stand? An overview of treatment technology and management practice. Water Sci. Technol. Water Supply 2005, 5, 77-85. [CrossRef]

16. Wintgens, T.; Melin, T.; Schäfer, A.; Khan, S.; Muston, M.; Bixio, D.; Thoeye, C. The role of membrane processes in municipal wastewater reclamation and reuse. Desalination 2005, 178, 1-11. [CrossRef]

17. Binz, C.; Harris-Lovett, S.; Kiparsky, M.; Sedlak, D.L.; Truffer, B. The thorny road to technology legitimation. Technol. Forecast. Soc. Chang. 2016, 103, 249-263. [CrossRef]

18. Dolnicar, S.; Hurlimann, A.; Grun, B. What affects public acceptance of recycled and desalinated water? Water Res. 2011, 45, 933-943. [CrossRef] [PubMed]

19. Dolnicar, S.; Schäfer, A.I. Public perception of desalinated versus recycled water in Australia. In Proceedings of the CD AWWA Desalination Symposium, Honolulu, HI, USA, 7-9 May 2006; pp. 1-13.

20. Schmid, S.; Bogner, F.X. Is there more than the sewage plant? University freshmen's conceptions of the urban water cycle. PLOS ONE 2018. submitted.

21. Suzuki, D. The Sacred Balance: Rediscovering Our Place in Nature, Updated and Expanded; Greystone Books Ltd.: Toronto, ON, Canada, 2007.

22. Ramsenthaler, C. Was ist "Qualitative Inhaltsanalyse?". In Der Patient am Lebensende; Schnell, M., Schulz, C., Kolbe, H., Dunger, C., Eds.; Springer Fachmedien Wiesbaden: Wiesbaden, Germany, 2013; pp. $23-42$.

23. World Health Organization (WHO). Declaration of Helsinki. Bull. World Health Organ. 2001, 79, 373-374.

24. Mayring, P. Qualitative Inhaltsanalyse: Grundlagen und Techniken(Beltz Pädagogik) Taschernbuch-2; Beltz: Weinheim, Germany, 2015.

25. Fremerey, C.; Liefländer, A.K.; Bogner, F.X. Conceptions about Drinking Water of 10th Graders and Undergraduates. J. Water Resour. Prot. 2014, 6, 1112-1123. [CrossRef]

26. Hurlimann, A.C. Is recycled water use risky?: An Urban Australian community's perspective. Environmentalist 2007, 27, 83-94. [CrossRef]

27. Marks, J.S. Taking the public seriously: The case of potable and non potable reuse. Desalination 2006, 187, 137-147. [CrossRef]

28. Marks, J.; Cromar, N.; Fallowfield, H.; Oemcke, D. Community experience and perceptions of water reuse. Water Sci. Technol. Water Supply 2003, 3, 9-16. [CrossRef]

29. Dolnicar, S.; Hurlimann, A.; Nghiem, L.D. The effect of information on public acceptance-The case of water from alternative sources. J. Environ. Manag. 2010, 91, 1288-1293. [CrossRef] [PubMed]

30. Rice, J.; Wutich, A.; White, D.D.; Westerhoff, P. Comparing actual de facto wastewater reuse and its public acceptability: A three city case study. Sustain. Cities Soc. 2016, 27, 467-474. [CrossRef]

31. Tsagarakis, K.P.; Mellon, R.C.; Stamataki, E.; Kounalaki, E. Identification of Recycled Water with an Empirically Derived Symbol Increases Its Probability of Use. Environ. Sci. Technol. 2007, 41, 6901-6908. [CrossRef] [PubMed]

32. Toze, S. Water reuse and health risks—Real vs. perceived. Desalination 2006, 187, 41-51. [CrossRef]

33. Drewes, J.E.; Kahn, S.J. Water Reuse for Drinking water augmentation. In Water Quality $\mathcal{E}$ Treatment: A Handbook on Drinking Water; McGraw-Hill Professional: New York, NY, USA, 2011.

34. Hurlimann, A.; Hemphill, E.; McKay, J.; Geursen, G. Establishing components of community satisfaction with recycled water use through a structural equation model. J. Environ. Manag. 2008, 88, 1221-1232. [CrossRef] [PubMed]

35. Hurlimann, A.; Dolnicar, S. When public opposition defeats alternative water projects-The case of Toowoomba Australia. Water Res. 2010, 44, 287-297. [CrossRef] [PubMed] 